\title{
Application of Armed Conflict Law in Non-war Military Operations
}

\author{
Ke Liu ${ }^{1, a}$ and Yunxia Song ${ }^{2, b}$ \\ ${ }^{1}$ Associate Professor, Political Officer Education and Training Department, PLA Dalian Naval \\ Academy \\ ${ }^{2}$ Professor, Political Officer Education and Training Department, PLA Dalian Naval Academy \\ amqson@qq.com, ${ }^{b} 31000345 @ q q . c o m$
}

Keywords: armed conflict law; non-war military operations; application

\begin{abstract}
With the expansion of national interests and the rise of non-traditional security threats, task fulfillment of non-war military operations has gradually become an important way for application of military forces. The non-war nature of non-war military operations has made it beyond the traditional scope of the armed conflict law. Some non-war military operations, due to their similarities in characteristics and forms to warring military operations, sometimes cause acts and consequences similar to military operations. Therefore, it is urgent to study the application of non-war military operations to the armed conflict law on limiting means and methods of military operations and imposing humanitarian protection of subjects and carefully discuss by international law researchers of various countries in non-war military operations.
\end{abstract}

\section{Introduction}

The armed conflict law, also known as international humanitarian law or law of war, is a part of international law, rules and norms applying wars or armed conflicts. Focusing on protection of people not directly involved in military operations (such as civilians) or no longer participating in military operations (such as non-effectives and prisoners) in wars or armed conflicts, demonstrating "humanity", these laws and legal rules are summarized as the international humanitarian law by the modern international law ${ }^{[1]}$. Like other legal disciplines, it is necessary to interpret and apply the rules and principles of the armed conflict law.

Non-war military operations are a new pattern of military actions that the international community takes to address non-traditional security threats. U.S. army believes that against the new international environment after the Cold War, the boundary between peace and war has become blurred. In 1993, U.S. Army classified the military operations into the 2 categories of "war" and "non-war military operations in its Operation Field Manual, initiating the concept of "non-war military operations." In 2001, the US Joint Chiefs of Staff defined non-war military operations in the "Joint Operations Outline" as "all applications of the military power of a country other than large-scale war operations." Subsequently, Russia, Japan, France and Italy included non-war military operations into the doctrine, taking enforcement of non-war military operations as an important function of the armed forces. Non-war military operations will inevitably cause "victims of military operations," including civilians, non-effectives, prisoners, and even behavioral agents represented by terrorist and pirates. Should the above subjects be humanely protected? Should non-war military operations follow armed conflict law? It is urgent to conduct in-depth discussion by international law researchers, and careful consideration of all countries in non-war military operations. 


\section{Application of non-war military operations to armed conflict law}

In peace, war or armed conflict, non-war military operations include operations against combat status and operations against non-combat status. The combat operations involved in non-war military operations include active combat operations and operations with multiple of combat weapons, and have many similarities with the war. ${ }^{[2]}$ There are many commonalities between wars, armed conflicts and non-war military operations. These commonalities form the basis for the application of armed conflict law in non-war military operations.

\subsection{War, armed conflict and non-war military operations safeguarding national rights and interests}

Judging from the action purpose, war, armed conflict and non-war military operations are all "military operations" taken by armed forces of a country, forcible measures to safeguard its interests. No matter what kind of military operations a country takes, its purpose is to seize and maintain its political and military initiative. The difference only lies in the scale. Therefore, in all military operations, implementation of armed forces needs to be governed by the armed conflict law in the combat means and methods.

\subsection{Legal protection for rights and interests of "victims of military operations" in non-war military operations}

Judging from operational consequences, force in non-war military operations inevitably leads to "victims of military operations." Although "victimization" can be caused differently, the victims impacted and affected by military operations need help physically and mentally. And their characteristics are the same as those of the victims of POW, non-effectives and civilians protected by the armed conflict law.

\subsection{Standardization of non-war military operations with the armed conflict law urgently needed by international development}

In response to non-traditional security threats, various countries take increasing non-war military operations, causing increasing "military victims of military operations". To safeguard basic rights and interests of this special group, it is necessary to have certain rules. And the armed conflict law is the most appropriate law. In practice, multiple countries consciously protect "victims" in accordance with the armed conflict law in non-war military operations. Moreover, some well-known experts and scholars mention in the same breath non-war military operations and wars and armed conflicts. For example, François Bugnion, director of Legal and International Affairs Department of the International Committee of the Red Cross, published Just War, Aggressive War and International Humanitarian Law in Moscow International Law Journal, putting together anti-terrorist operations and wars for discussion of issues related to the armed conflict law.

\section{Specific application of international humanitarian law in non-war military operations}

US army classifies non-war military operations into the 3 categories of combat operations, transitional operations and non-combat operations. The following is the discussion about the application of the armed conflict law against the 3 non-war military operations.

\subsection{Belligerent non-war military operations}

Belligerent non-war military operations usually involve forcible combat, including forcible sanctions (maritime interception), forcible isolation and escort operations, attacks and strikes. 
Although not a war, belligerent non-war military operations are military operations similar to the war. In the operations, it is common to apply force for fighting. In such cases, it is necessary to apply the armed conflict law for protection.

\subsection{Transitional non-war military operations}

Transitional non-war military operations are at the transitional zone between combat and non-combat operations. The specific modalities include anti-terrorist operations, anti-narcotics operations, commercial transport freedom, non-combat evacuation operations, peacekeeping operations, and search and rescue operations.

The above actions may require force for combat. In terms of transitional non-war military operations requiring force for combat, it is necessary to apply the armed conflict law to impose restrictions on the force means and methods. It is true that terrorists and pirates are different status from common prisoners of war. For example, they do not belong to legal war belligerents and do not abide by rules of engagement. Therefore, it is necessary for the contracting states to take action against them. However, another possible consequence of military operations is weakening some rules states must obey in judicial proceedings. For example, some countries failed to conduct criminal prosecutions or judicial review of persons suspected of conducting terrorist acts, instead, they adopted administrative detention. Required by international human rights law, suspected terrorists or pirates, members of armed forces or civilians, should have their basic human rights protected, including other remaining rights, such as legal trial, fair conviction and sentence under procedural and substantive laws. Therefore, to avoid unnecessary suffering or undue harm to these particular subjects, it is necessary to apply the rules of armed conflict law.

\subsection{Non-combatant non-war military operations}

Non-combatant non-war military operations include disaster management, civil assistance, humanitarian aid, foreign aid, force demonstration, support for insurgency or counter-insurgency operations.

The non-war military operations may be implemented locally or in allied countries because they do not require force and therefore there is no question of application of the armed conflict law.

\section{Development of the armed conflict law by non-war military operations}

As the youngest subject in international law, the armed conflict law is developing at a rate far exceeding that of any other subject in the international legal system. The emergence of non-war military operations will further promote development of the armed conflict law.

\subsection{Breakthrough of the war scope under the traditional international law}

Against the current international situation, the forms of war become increasingly diverse. In some cases, they are replaced by armed conflicts or non-war military operations. As an armed conflict law arose from the "harmony of humanitarian law with war necessity". It is necessary to adapt to changes in the war forms, and try to ease the atrocities committed by wars on the basis of human conscience to a certain extent, extending from a war to an international armed conflict (not an international armed conflict) and even a non-war military operation, making the scope of application of the armed conflict law even wider.

\subsection{Complementing international human rights in judicial guarantees}

Although armed conflict law and international human rights law have different historical 
backgrounds and unique rules, and operations in different ways, they have the same core, namely safeguarding human dignity. What they have in common in the adjustment of non-war military operations is that their primary purpose and their fundamental role are to seek the protection of the rights of human beings, that is, protecting the life and dignity of individuals, preventing and punishing tortures, and ensuring criminal proceedings and basic judicial enjoyment. In some areas, there is still some making-up between the two.

First of all, non-war military operations have contributed to their time-consuming competition. International human rights law is mainly applied in peacetime and belongs to international laws in peacetime. It is a legal rule for people to be protected in peacetime. The armed conflict law applies to war and armed conflicts, and belongs to wartime international laws. It is a war or armed conflict. In the extraordinary period, it is necessary to protect people according to the legal rules. However, "non-war military operations" may take place both in wars and in armed conflicts or in times of peace, resulting in a time-consuming competition between the armed conflict law and the international human rights law.

Second, non-war military operations have also brought about matching between the two. International human rights law mainly regulates and adjusts the legal relationship between the state and its own citizens. The armed conflict law, on the other hand, mainly stipulates the state's treatment of the rules to be followed by its enemies and citizens, especially the victims of war such as prisoners of war, non-effectives, civilians and other special groups. The "victims of military operations" arising from "non-war military operations" may be both nationals and foreign nationals. Any definition of "non-war military operations" will inevitably have a common impact on the applicability of the two.

Third, international human rights law supplements the armed conflict law on a substantive and procedural level. At the substantive level, the articles of the international human rights law treaties go beyond the traditional armed conflict law, such as the Covenant of Civil and Political Rights, filling in some normative loopholes. At the procedural level, international human rights treaties contain sophisticated enforcement mechanisms, such as the identification of the status of terrorists and other aspects of the law to supplement the application of junior laws. As for war crimes committed in violation of the armed conflict law in war, they are tried by the International Military Tribunal after the war and by the ICTY for serious crimes against the armed conflict law in non-international armed conflicts. The two cooperate and supplement each other.

To sum up, the armed conflict law has the following 2 basic characteristics:

First, it is necessary to protect victims of war, including non-effectives, prisoners of war, and civilians. The regulations of the armed conflict law on the protection of victims are the core of the international humanitarian system. It is both a right and an obligation of the state. The existence of combat action is the condition for the armed conflict law;

Second, humanitarian protection does not differ in the nature and scale of combat operations. In other words, the armed conflict law does not apply on the basis of the legitimacy of the war on the premise that illegal operations can not be grounds for denying the armed conflict law. Its rules and habits are only about the norms of combat operations, and it has nothing to do with the nature of combat operations.

To this end, this author believes that in case of non-war military operations (especially applying force), it is necessary to consider the application of the armed conflict law. The State needs to implement the armed conflict law not only in times of war, but also in times of peace. Implementation is an important national obligation. ${ }^{[3]}$ 


\section{References}

[1] Collection of Articles from the International Review of the Red Cross: (2003) Zhu Wenqi, Beijing: Chinese People's Liberation Army Publishing House, 2005.

[2] Military Law Review Series: Volume 2009, Xue Gangling, Beijing: China Fangzheng Publishing House 2010.

[3] International Humanitarian Law: Zhu Wenqi, Beijing, China Renmin University Press, 2007. 